Administração de estoques, teoria e prática

Por Paulo Sérgio Gonçalves e E. Schwember. Rio de Janeiro, Interciência, 1979. 257 p. Ilustrado, brochura, indicada simbologia e bibliografia geral e por capítuio.

Finalmente existe, em português, um livro de estoques escrito por um engenheiro e um economista, ambos com prática empresarial principalmente na área de suprimento de energia elétrica. O primeiro tem mestrado em engenharia de produção e o segundo, especialização em computação Assim, com um background excelente para o trabalho de escrever um livro sobre a teoria e prática matemática dos estoques lgrifamos matemática, pois quem esperá encontrar algo sobre empilhadeiras e fluxo de materiais deve procurar outras obras), os autores não decepcionam os interessados. O livro se destina aos técnicos que trabalham dentro de médias e grandes empresas com controles aperfeiçoados de estoques e procedimentos de planejamento dos mesmos. Na opinião do autor da resenha, que administra cursos de graduação e pós-graduação dessa área há mais de 20 anos, a obra atende melhor aos cursos de pósgraduação, tanto em engenharia e economia, quanto em administração de empresas e eventualmente pública. Por exemplo: nos cursos de graduação, pouco adianta ensinar a abstração da teoria de atendi- mento e o planejamento de estoques de segurança, o que importa é a fixação de estoques de pedido. É mais importante esclarecer como o acompanhamento deve ser ferto para que o fornecedor não se atrase, do que mostrar como o.atraso médio pode ser probabilisticamente levado em consideracaão por melo de desvio padrão da curva de Gauss ou distribuicãa de Poisson - veja p. 72 e 73. Nos cursos de pós-graduação, no entanto, tais fatos são básicos

Recomendamos, portanto, a livro de Gonçalves, na íntegra, para cursos de pós-graduação de administração de estoques ou materiais, enquanto admitimos que apenas algumas partes constıtuem leitura nos cursos de graduação. Assim, mesmo num curso de pósgraduação em administração, com o emprego de multıplicadores de Lagrange, para a fixação de uma composição ótima do estoque, fora do lote econômico, provoca dificuldades matemáticas, relativas. Não deve ser o único livro para pós-graduação, mas certamente é básico - e plenamente satisfatório.

O livro não tem índice remissivo - problema de muitos livros nacionais - e não possui questões e casos a resolver, o que não é defeito, pois podem ser encontrados em outra obra. A bibliografia é muito boa e completa. Provavelmente não fez parte dos planos dos autores para constar do livro um artigo nosso relativo a aplicação de lote econômico para diver sos componentes de um conjunto. $O$ indice é o seguinte:

1 - Previsões

2 - Os custos dos estoques

3 - Estoques de segurança

4 - Quantidade e periodicidade econômica

5 - Operações dos sistemas de estoques

6 - O sistema de planejamento dos requerimentos (MRP)

7 - Peças de reserva e simulação

8 - o computador na administração de materiais

9 - Aspetcos complementares Simbologia

Bibliografia
O conteúdo dos capítulos é na maioria de cunho quantitatıvo, puramente probabilístico - ma temático e sem erros, graças a uma excelente revisão. A parte gráfica está multo bem cuidada, a leitura é fácil. Somente no capítulo 6, temos certa dúvida quanto à precisão do português, a saber: a volta da palavra requerimento, como tradução de requirement, isto é, necessidade. A última vez que a encontramos, com o mesmo significado, foi na tradução do livro de Muther sobre layout. Mas este livro não é tradução, foi escrito por um brasileiro e um chileno. Requerimento manda-se para uma repartıção, necessidade é exigência das empresas. Portanto, se não houver cuidado, vamos entrar, depois do economês e do computadorês lque tivemos ocasião de apreciar também com palavras como "formatar") e do burocratês lagılizar, ou ainda "operacionalizar" e "operacionalizamento"), no planejamentês. E essa observação é o único senão dessa obra.

Um livro de administração de estoques deve começar com "como planejar o consumo no futuro". Exceto pela falta do método de Leontieff (de coeficientes setoriais), o livro ensina todos os rnétodos importantes de previsão: regressão 〈só a linear, mas as outras constam, por exemplo, da cápsula de programas n. 3 do computador de bolso T1 58 e 59, exponencial e logarítmical, a média móvel simples e nivelada exponencialmente e a verificação de efeitos sazonais.

No segundo capítulo nos agradou muito a comparação entre custos fixos e variáveis por pedido, enquanto as 30 páginas do capítulo 3 formam um excelente estudo sobre estoque de segurança e grau de serviço. O lote econômico no capítulo 4, quanto a compras e fabricação, é apresentado com muita clareza. Com uso de material escrito pelo Prof. Marcos Vasconcellos da EAESP/FGV, em apostila de distribuição interna na FGV citada na bibliografia - o sistema $A B C$ é apresentado com técnica 
completa. E os autores caem em nossa simpatia, porque ensinam como fazer um ábaco e como trabalhar na monografia. Essa arte, ensinada no Brasil há mais de 30 anos nas escolas superiores de engenharia e arquitetura sob o nome de cálculo gráfico e monografia, desapareceu com as diversas reformas do ensino, a favor de matérias que pareciam, eventualmente, à primeira vista, de maior importância. Assim, os atuais formandos não conhecem a fabricação do ferramental do cálculo, passando rápido pela monografia, muitas vezes a partir da mesma fórmula e com as mesmas constantes de problemas repetitivos.

Realmente hoje, com programas de software e com calculadoras de bolso, da HP e Tl plenamente programadas para todos os cálculos, que antes eram graficamente resolvidos, torna-se desnecessário saber como construir um ábaco.

Sobre o planejamento, encontra-se tudo no capítulo 6 , mas insa-

ciavelmente achamos que também seria "requerida" uma rèferência à Dinâmica industrial de Forrester ou ao livro citado na bibliografia de Holt, Modigliani e colaboradores, sobre o planejamento da produção, de estoques e de mão-deobra. Os autores empregam algumas das técnicas do livro de Harvey Wagner, citado na bibliografia do capítulo e na geral, inclusive o. algoritmo, contribuindo, asşim, com um teor de pesquisa operacional bem elevado.

No sétimo cápítulo, encontra-se a técnica de probabilidade de quebra e a quantidade e a periodicidade da compra de peças de reposição.

Como numa obra do tamanho desta nem todos os métodos dé determinaçăo são passiveis de consideração, não achamos importante a falta da técnica de matriz de decisão e de análise marginal de Bowman e Fedder, aplicada a peças de reposição. O capítulo de programação de computador é conciso e bom. Talvez falte uma listagem de programas existentes à disposição do público brasileiro, como software de compra ou aluguel fácil.

E assim, resumindo, temos um ótimo livro, que preenche uma necessidade do currículo de pós-graduação e de empresas que controlam os estoques com métodos mais científicos que simples fixação de estoques mínimos ou pontos de pedido. Para os cursos dé graduação, uma leitura de alguns capitulos tornaria os formandos mais aptos a usar os modernos sistemas de planejamento e controle da produção. No livro não há referências a compras feitas por empresas comerciais, mas a técnica, principalmente da teoria de serviço ou atendimento, é a mesma. Assim, o público leitor dessa obra deve ser bastante vasto.

Kurt E. Weil

\section{Raízes do futuro}

Pelo Club de l'Horloge. Paris, Masson, 1977.

Raízes do futuro é o título de um livro que provoca interesse, escrito por um grupo de dedicados jovens intelectuais franceses. Formam eles o Clube do Relógio iClub de l'Horlogel - na consciência de que, relativamente a uma solução para urgentes problemas sociais e políticos, faltam apenas cinco minutos para as doze horas.

Raizes do futuro poderia, entretanto, ter sido escrito por qualquer grupo de jovens intelectuais, cujo país estivesse em crise, e que se encontrassem fortemente motivados, não só a procurar uma solução para a crise, mas também a compartilhá-la com o seu povo. ${ }^{10}$ livro foi publicado nas vésperas das eleições presidenciais francesas. Reflete a sensibilidade dos jovens intelectuais às críticas opções futuras, que deverão ser assumidas conscientemente por todos os interessados.

De acordo com o Clube do Relógio; a. França deverá forjar o seu futuro sobre as raízes do seu passado. A França não deveria importar modelos alheios de desen-

1 Portanto, qualquer referência feita à Franca pode ser aplicada - mutatis mutandis - a qualquer outro país em crise. 